\title{
DOI https://doi.org/10.30525/978-9934-26-181-7-32
}

\section{SOCIOLOGICAL DIMENSIONS OF SOCIAL REALITY STUDIES}

\author{
Tegleva Yu. \\ Teacher of Informatics \\ NVO - lyceum NIT tem \\ Kravtsov Yu. \\ Doctor of Philosophical Science, Professor, \\ Professor at the Department of Sociology \\ Dniprovsk State Technical University \\ Kamianske, Ukraine
}

The course of development of sociological knowledge and its methodology shows, that gradually, from century to century, not only the object of cognition, but also subject of cognition, as well as its methodological toolkit naturally change in the process of accumulation of knowledge and improvement of the methodology. Recently, the concepts of virtual reality and, at the same time, the idea of virtualization of society are being developed intensively.

The event allows you to deal with meaningful fragments of human life. It may be or may not be.Finding ways to build a new ontology of social reality, going beyond the existing stereotypes, reveals the problem of linking the process of improving the quality of education with its substantive forms of implementation. An analysis of the role of communicative rationality in "social design" offers a new way of understanding existing educational practices and opens up new ranges of opportunities.

The post-modern man, immersed in social reality, perceives it seriously as a natural given, in which he had to live. As opposed to him "post-modern man, - writes, M.K.Мaмardashvili, - passionately "lives" in it, realizing its convention, manageability of its parameters and possibility to enter it" [1, p.76].

For phenomenology, substantive idea is an idea, in which space and validity are not transcendental in some mystical sense kind of thing inside it: exactly phenomenal space, phenomenal space-time reality is transcendental. In conditions of many complementary forms of knowledge the subject needs enablers of excessive semantic surplus reduction. In addition to the flexible structure of the text, a "text machine", which allows you to remain the large volumes of information and manage it and to facilitate the process of producing texts, is needed. Hypertext is the main form of "organization" on the Internet, it is described as decentralization in Landau, as a semblance of Delos's "rhizomes" 
as a "revolution" in research, as something that gives unlimited power to manipulate symbols, texts and images. Therefore, hypertext, as a way of communication and knowledge organization, includes just the knowledge (text), computer and software.

This greatly complicates the description of the hypertext, it slips out and cannot be determined. The Internet user thus lives and communicates in terms of inclusion in thehypertext space."Ranking in one way or another other people on the Internet (represented by a set of texts) and doing this purposefully or occasionally, in particular ranking the potentialcommunication partners or those with whom the contacting is undesirable, every person creates his own fragment of social virtual reality. And creates... in the form of hypertext: sets of texts that display specific people, placed in the imaginary space and are connected to each other by significant relationships" [2, p.p. 36-38].

Therefore, the fundamentality of modern humanities education is determined not by the translation of fundamental knowledge, due to the loss of universal and unified research context, but by the focus on the formation of creativity as a fundamental structure of human existence, the conceptualization of activities that have productive theoretical potential.

Informativeness is the core of a dialogue that reveals the intersubjective world of personality, the system of his personal knowledge and abilities to use them in finding the truth. Dialogue as a form of finding the truth is the moments of enlightenment of its participants, aimed at the line of the formulated problem, and in dialogue work both our rationality and our intuition. Dialogue is a form of expression and a way of realizing of our needs. It manifests itself in a communicative worldview, it embodies the aspiration for integrity, creation and understanding.

Thus, in the educational process as forms of subjects communication of this process in the course of the truth comprehension, the dialogue belongs as a value form, in which the epistemological aspect of education is most clearly revealed. If the discussion does not always have a pronounced militant character during the discussion, the etymology of the word "polemics" comes from the Greek "polemus" - the war. The controversy in the broad sense - is a polemic that arose after an interestingly formulated problem, and a discussion in connection with one or another new task. The controversy is a characteristic feature of communication in everyday life.

\section{References:}

1. Мамардашвили М. К. Классический и неклассический идеалы рациональности. Тбилиси: Мецниереба, $-1984 .-82$ с. 
2. Wittgenstein L. Philosophische Untersuchungen. Ludwig Wittgenstein. Werkausgabe, Bd.1-8, Frankfiirt/M:Suhricamp, 1984, Bd.1,P. 394-977.

DOI https://doi.org/10.30525/978-9934-26-181-7-33

\title{
ФОРМИРОВАНИЕ ОТНОШЕНИЯ К СЕБЕ И МИРУ КАК ФАКТОР ТРАНСФОРМАЦИЙ
}

\author{
Шедяков В. Е. \\ доктор социологических наук, \\ независимый исследователь \\ г. Киев, Украина
}

\begin{abstract}
...Каждый человек может стать художником своей жизни и установить с миром - как бы это выразиться поточнее?.. - отношения взаимотворчества! ... Конечно, нелегко отличить суть жизни от суеты, тем более что «кажимость» всегда норовит выдать себя за сущиность. Но жизнь в суете, жизнь кое-как, без оглядки, когда человек не успевает задуматься, куда и зачем он идёт (да, собственно, никуда он и не идёт, хотя всё время спешит), рано или поздно мстит опустошённостью...

В.Д. Пришвина
\end{abstract}

Соответствие результата трансформаций предполагаемой модели во многом зависит не только от её качества, но и от особенностей субъекта, объекта и процесса изменений. В частности, высоко воздействие на восприятии действительности самоощущения человека и картины его представлений, во многом формируемых в ходе получения образования. От подготовки к образу жизни, воспитания самокритичности и рефлексии, качества восприятия, отправных ценностно-смысловых комплексов, постановки целей педагогики зависят не только поведенческие особенности индивида, но и вектор общественных идеологии и психологии культурно-цивилизационного мира. Социокультурный организм ойкумены может быть чреват как новой социальной жизнью, так и смертью цивилизации. При глобальном масштабе взаимодействии и накоплении оружия массового уничтожения эгоцентризм и инфантилизм, нежелание и неготовность к принятию других, отличающихся от 